\title{
A Pilot Study Suggests that the G/G Genotype of Resistin Single Nucleotide Polymorphism at -420 May Be an Independent Predictor of a Reduction in Fasting Plasma Glucose and Insulin Resistance by Pioglitazone in Type 2 Diabetes
}

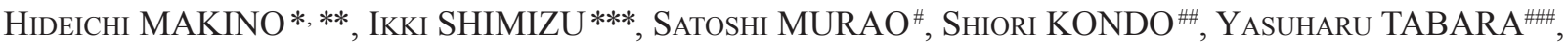 \\ MASAO FUJIYAMA ${ }^{+}$, YASUHISA FUJII*, YASUHARU TAKADA ${ }^{++}$, KAZUAKI NAKAI ${ }^{++}$, KENICHI IZUMI ${ }^{\# \#, ~}$ \\ JUN OHASHI ${ }^{\dagger}$, RYOICHI KAWAMURA**, JUNKO YAMAUCHI**, YASUNORI TAKATA**, WATARU NISHIDA**, \\ MitSURU HASHIRAMOTO**, HIROSHI ONUMA**, ${ }^{* \dagger}$ AND HARUHIKO OSAWA**, \\ * Institute of Diabetes Research Center, Takanoko Hospital, Ehime 790-0925, Japan \\ ** Department of Molecular and Genetic Medicine, Ehime University, Graduate School of Medicine, Ehime 791-0295, Japan \\ *** Ehime Prefectural Central Hospital, Ehime 790-0024, Japan \\ "Matsuyama-Shimin Hospital, Ehime 790-0067, Japan \\ \# Matsuyama Red Cross Hospital, Ehime 790-8524, Japan \\ \#\# Department of Basic Medical Research and Education, Ehime University, Graduate School of Medicine, Ehime 791-0295, Japan \\ Fujiyama Clinic, Ehime 790-0003, Japan \\ ${ }^{++}$Saijo Central Hospital, Ehime 793-0027, Japan \\ ${ }^{+++}$Ehime Rosai Hospital, Ehime 792-8550, Japan \\ ${ }^{\dagger}$ Doctoral Program in Life System Medical Sciences, Graduate School of Comprehensive Human Sciences, University of Tsukuba, \\ Ibaraki 305-8571, Japan \\ i† Ehime Proteo-Medicine Research Center, Ehime University, Ehime 791-0295, Japan \\ The above-mentioned organizations are Ehime Diabetes Study Group.
}

\begin{abstract}
The aim of this study was to determine the relation between the G/G genotype of a resistin gene promoter single nucleotide polymorphism (SNP) at -420 (rs1862513) and glycemic control by pioglitazone in type 2 diabetes. In Study 1 , 121 type 2 diabetic patients were treated with pioglitazone (15 or $30 \mathrm{mg} /$ day) for 12 weeks, in addition to previous medication. In Study 2, 63 patients who had been treated with pioglitazone for 12 weeks were examined retrospectively. In Study 1, multiple regression analysis revealed that the $\mathrm{G} / \mathrm{G}$ but not $\mathrm{C} / \mathrm{G}$ genotype was correlated with a reduction in fasting plasma glucose (FPG) and homeostasis model assessment of insulin resistance (HOMA-IR) compared to C/C. When adjusted for age, gender, and BMI, the $\mathrm{G} / \mathrm{G}$ genotype was an independent factor for the reduction of FPG $(P=0.020)$ and HOMA-IR $(P=0.012)$. When studies 1 and 2 were combined by adjusting the studies, age, gender, and BMI, the reduction of $\mathrm{HbA} 1 \mathrm{c}$ was correlated with the $\mathrm{G} / \mathrm{G}$ genotype $(\beta=-0.511, P=0.044)$. Therefore, this pilot study suggests that the $\mathrm{G} / \mathrm{G}$ genotype of resistin SNP -420 may be an independent predictor of the reduction of fasting plasma glucose and HOMA-IR by pioglitazone.
\end{abstract}

Key words: Pioglitazone, Resistin, SNP, Insulin resistance, Type 2 diabetes

(Endocrine Journal 56: 1049-1058, 2009)

PIOGLITAZONE, a member of thiazolidinediones (TZDs), is a peroxisome proliferator-activated receptor- $\gamma$ (PPAR- $\gamma$ ) agonist developed as an antidi-

Received Nov. 5, 2008; Accepted Aug. 17, 2009 as K08E-320 Released online in J-STAGE as advance publication Sep. 9, 2009

Correspondence to: Hideichi MAKINO, M.D., Ph.D. and Haruhiko OSAWA, M.D., Ph.D., Institute of Diabetes Research Center, Takanoko Hospital, Matsuyama, Ehime 790-0925, Japan, and Department of abetic drug to enhance the action of insulin [1]. TZDs can improve hyperglycemia in patients with type 2 diabetes $[2,3]$. In addition, a number of studies suggest

Molecular and Genetic Medicine, Ehime University Graduate School of Medicine, Shitsukawa, Toon, Ehime 791-0295, Japan. E-mail: hidemak@takanoko-hsp.jp; harosawa@m.ehime-u.ac.jp The first 2 authors contributed equally to this work. 
that TZDs confer clinical benefits beyond a glucoselowering effect, such as improvement of dyslipidemia and atherosclerosis $[4,5]$. Recently it was reported that pioglitazone was effective in secondary prevention of macrovascular events in diabetic patients with high cardiovascular risk [6], whereas rosiglitazone increased the cardiovascular risk in diabetic patients [7]. Although the first TZD, troglitazone, had been withdrawn because of hepatic failure, no case of hepatic failure was reported in the large-scale prospective study of pioglitazone [8]. On the other hand, pioglitazone and rosiglitazone promote body weight gain in vivo and adipogenesis in vitro. Fluid retention and edema are common side effects of these drugs. It has been recognized that some type 2 diabetic patients respond to TZDs with the improved hyperglycemia (responders), whereas others do not (non-responders) [9]. Single nucleotide polymorphism (SNP) of genes contributing to body weight gain or edema by TZDs has been reported $[10,11]$. However, genetic factors affecting improvement of hyperglycemia remain to be determined.

Resistin was identified as a gene whose expression is induced by adipocyte differentiation and inhibited by PPAR- $\gamma$ agonists in 3T3-L1 cells [12]. Resistin is secreted from adipocytes in mice, and its serum levels are increased in obese diabetic mice. PPAR- $\gamma$ agonists reduce serum resistin levels in mice as well as in humans. Mice overexpressing the resistin gene (retn) in the liver have greater serum resistin and insulin resistance, whereas resistin (-/-) mice have reduced fasting blood glucose $[13,14]$. Therefore, it can be concluded that elevated serum resistin levels cause insulin resistance in rodents. Human resistin gene (RETN) is rarely expressed in adipose tissues, but it is expressed at high levels in monocytes or macrophages $[15,16]$. This is in contrast to its dominant expression of retn in adipose tissues in mice [12]. Macrophages infiltrating adipose tissue could account for the observed insulin resistance in obese mice, suggesting a possible role of resistin in insulin resistance in humans [17]. The role of RETN in human T2DM or obesity has been controversial in studies of the association of SNPs or serum resistin levels [18-23].

Our group recently reported that the $\mathrm{G} / \mathrm{G}$ genotype of RETN promoter single nucleotide polymorphism (SNP) at -420 (rs1862513) is associated with T2DM susceptibility [24]. Sp1 and Sp3 transcription factors specifically bind to the DNA element including $-420 \mathrm{G}$, resulting in an enhanced promoter activity. RETN mRNA in monocytes is positively associated with its simultaneous serum levels and is highest in subjects with the G/G genotype [22]. Serum resistin levels are higher in T2DM subjects than in controls, and highest in subjects with the $\mathrm{G} / \mathrm{G}$ genotype, followed by the $\mathrm{C} / \mathrm{G}$ and $\mathrm{C} / \mathrm{C}$ genotypes. Therefore, the specific recognition of $-420 \mathrm{G}$ by $\mathrm{Sp} 1 / 3$ appears to increase RETN promoter activity, which could induce insulin resistance and human T2DM through enhanced monocyte mRNA and serum levels of resistin. Thus, the relation between SNP-420 and factors related to improvement of glycemic control merits further investigation in T2DM.

The aim of this study was to determine the role of RETN SNP -420 in the improvement of hyperglycemia and insulin resistance by pioglitazone treatment in type 2 diabetic patients.

\section{Subjects and Methods}

\section{Subjects}

Patients with type 2 diabetes were recruited from the outpatient clinics at Ehime University Hospital, Ehime Prefectural Hospital, Matsuyama-Shimin Hospital, Matsuyama Red Cross Hospital, Fujiyama Clinic, Saijo Central Hospital, and Ehime Rosai Hospital. We performed both a prospective study (Study 1) and a retrospective study (Study 2) simultaneously from February to December in 2005. All patients were informed of the purpose of the study, and their written consent was obtained. The study was approved by the ethics committee of the respective hospitals. All patients were instructed to maintain the same levels of energy intake and physical activity throughout the study. Medical check-ups were done every 4 weeks. Fasting serum and plasma samples were collected only in Study 1. Fasting plasma glucose (FPG) was measured at 0,4 , 8 , and 12 weeks, along with other indices: $\mathrm{HbAlc}$, fasting serum levels of resistin, adiponectin, and insulin, the homeostasis model assessment of insulin resistance (HOMA-IR), and high-sensitivity C-reactive protein (hsCRP). It should be noted that we included all the subjects for ANOVA in the present study although HOMA-IR is not necessarily accurate when FPG is more than $140 \mathrm{mg} / \mathrm{dL}$. 
Study 1: Prospective study

A total of 121 patients (67 males and 54 females) were given $15 \mathrm{mg}$ pioglitazone daily for the first 4 weeks and $30 \mathrm{mg}$ for the next 8 weeks, or given $30 \mathrm{mg}$ through 12 weeks, without changes in their previous medication. The number of patients prescribed oral hypoglycemic agents were as follows: sulfonylurea, 110; metformin, 45; $\alpha$-glucosidase inhibitor, 19; and, glinide, 9. Type 2 diabetic patients with $\mathrm{HbAlc}$ values from 6.5 to $12.0 \%$ were enrolled in this study. There were four inclusion criteria: 1) age between 35 and 85 years; 2) BMI between 16 and $35 \mathrm{~kg} / \mathrm{m}^{2}$, 3) stable glycemic control and no medication changes in the previous three months; and, 4) no history of PPAR- $\gamma$ agonist treatment. Since the above criteria included broader range of type 2 diabetic patients, age, gender, and BMI were adjusted where indicated. The study excluded patients with type 1 diabetes; those receiving insulin therapy; those with cardiac, hepatic, renal or other chronic diseases; and pregnant or lactating women.

\section{Study 2: Retrospective study}

A total of 63 patients $(25$ males and 38 females, none of whom were in Study 1) were enrolled in Study 2 with the same criteria as described in Study 1. The patients who had been treated with 15 or $30 \mathrm{mg}$ of pioglitazone for 12 weeks were analyzed retrospectively. The number of patients prescribed oral hypoglycemic agents were as follows: sulfonylurea, 56; metformin, 30; $\alpha$-glucosidase inhibitor, 20; and, glinide, 3 .

The mean age, the duration of diabetes, and the body weight were similar in Studies 1 and 2, but the frequency of female patients, BMI, and $\mathrm{HbA} 1 \mathrm{c}$ levels were significantly greater in Study 2 than in Study $1(P=0.031, P=0.046$ and $P<0.001$, respectively $)$. There were no differences in the frequency of the resistin SNP-420 genotype between Studies 1 and 2 . The genotype distribution of SNP-420 was in HardyWeinberg equilibrium in both Studies 1 and 2.

\section{SNP typing}

PCR direct sequencing was performed as previously described $[21 ; 24]$. To type SNP-420, sequences of minus strands were checked using the pr1R primer. The other strand was sequenced, when required.
Measurement of serum resistin, adiponectin and hsCRP levels

Serum resistin levels were measured using a human resistin ELISA kit (R \& D Systems, Inc.) following the manufacturer's protocol. According to manufacturer data, the limit of detection is $0.16 \mathrm{ng} / \mathrm{mL}$, and the intra-assay coefficient of variation $(\mathrm{CV})$ is $<5 \%$ for low levels, and $<4 \%$ for high levels. Inter-assay $\mathrm{CV}$ was $<9 \%$ for low and high levels. The recovery was more than $90 \%$. We confirmed that the linearity was maintained below $0.16 \mathrm{ng} / \mathrm{mL}$, and both intra-assay $\mathrm{CV}$ and inter-assay $\mathrm{CV}$ were comparable to manufacturer specifications of 2.6-10.5\%. The antibodies in this ELISA have no detectable cross-reactivity to mouse resistin and other cytokines in human serum. The kit used had good correlation with the kit used in the previous study $(\mathrm{r}=0.987, \mathrm{y}=1.040 \mathrm{x}+0.469, \mathrm{y}$, this kit, $\mathrm{x}$, LINCO's kit) $[22,24,25]$. Serum total adiponectin was measured using a commercially available sandwich ELISA kit (Otsuka Pharmaceuticals, Tokyo, Japan), as previously described [26]. The inter- and intra-assay coefficient variations $(\mathrm{CV})$ of the adiponectin assay were both acceptable as described [27]. Plasma hsCRP concentration was measured using a previously validated assay system (Dade Behring Inc.) [28]. The inter- and intraassay coefficient variations of the hsCRP assay were 3.2 and $6.7 \%$, respectively.

\section{Statistical analysis}

To examine the effects of SNP-420 on $\Delta \mathrm{FPG}$ (12 minus 0 weeks), and $\triangle$ HOMA-IR (12 minus 0 weeks) in Study 1, a multiple regression analysis involving either $\triangle \mathrm{FPG}$ or $\triangle \mathrm{HOMA}-\mathrm{IR}$ as a dependent variable, was employed. Model 1: SNP-420 genotype, C/ $\mathrm{C}, \mathrm{C} / \mathrm{G}$, and $\mathrm{G} / \mathrm{G}$ were denoted by two dummy variables $(\mathrm{c} 1, \mathrm{c} 2)=(0,0),(1,0)$, and $(0,1)$, respectively, and were involved as independent variables. This first dummy variable estimates the difference between $\mathrm{C} / \mathrm{G}$ and $\mathrm{C} / \mathrm{C}$, and the second between $\mathrm{G} / \mathrm{G}$ and $\mathrm{C} / \mathrm{C}$. Model 2: In addition to model 1, age, gender (male $=1$, female $=2$ ), BMI, and total dose of pioglitazone during the 12 weeks (mg) were involved as independent variables. To adjust effects of oral hypoglycemic agents, treatment of sulfonylurea (with $=1$, without $=0$ ), metformin (with $=1$, without $=0$ ), $\alpha$-glucosidase inhibitor (with $=1$, without $=0$ ), and glinide (with $=1$, without $=0$ ) were further involved as independent variables in ad- 
dition to model 2. When Studies 1 and 2 were combined for analyzing $\Delta \mathrm{HbA} 1 \mathrm{c}$ (12 minus 0 weeks) as a dependent variable, the heterogeneity of the studies was adjusted as an independent variable (Study $1=1$, Study $2=2$ ), in addition to age, gender, and BMI. This model was further assessed by adjusting the total dose of pioglitazone during the 12 weeks (mg). To examine the effect of SNP-420 on HOMA-IR at 0 weeks in Study 1, a multiple regression analysis involving SNP420 (c1, c2) as independent variables, and HOMA-IR as a dependent variable was used. Either paired $t$ test, ANOVA, Kruskal-Wallis test, or Chi-squared test was used where indicated. All analyses were performed with a commercially available statistical package (SPSS Ver 14.0, SPSS Inc., Chicago, IL).

\section{Results}

The clinical characteristics of the patients before and after pioglitazone treatment are shown in Table 1. In Study 1, the FPG and HbA1c levels were decreased significantly from $169.2 \mathrm{mg} / \mathrm{dL}(9.4 \mathrm{mmol} / \mathrm{L})$ to 132.9 $\mathrm{mg} / \mathrm{dL}(7.4 \mathrm{mmol} / \mathrm{L})$, and from $8.1 \%$ to $7.2 \%$ after 12 weeks of treatment. Mean body weight and body mass index (BMI) were significantly higher after pioglitazone treatment. The fasting serum resistin levels were decreased significantly after pioglitazone treatment $(12.3 \pm 6.4 v s .10 .7 \pm 5.8 \mathrm{ng} / \mathrm{mL}$, paired $t$ test, $P<0.001)$. Adiponectin levels were increased 2.5 fold after pioglitazone treatment $(P<0.001)$. Insulin resistance was improved as shown by HOMA-IR and insulin levels. HsCRP was decreased significantly after pioglitazone treatment. In Study 2, HbA1c levels were significantly decreased after 12 weeks of treatment whereas mean body weight and BMI were significantly higher after pioglitazone treatment.

To assess the relation between the reduction (12 minus 0 weeks; $\Delta$ ) of either FPG or HOMA-IR and that of either resistin, adiponectin, or hsCRP, multiple regression analysis adjusted for age, gender, and BMI was employed since pioglitazone is known to be more effective in females and obese subjects [8]. In these factors, $\Delta$ resistin but not $\Delta$ adiponectin, or $\triangle$ hsCRP was positively correlated with $\triangle \mathrm{FPG}(P=0.0291$, 0.2678 , and 0.1050 , respectively). These findings suggest that resistin SNP-420 genotype, which has been reported to be tightly correlated with circulating resistin $[22,24,25]$, may be associated with the improve-
Table 1. Characteristics of patients with type 2 diabetes before and 12 weeks after pioglitazone treatment.

\begin{tabular}{lccc}
\hline Study 1 & Before & After & $P$ \\
\hline BW $(\mathrm{kg})$ & $60.5 \pm 10.2$ & $61.7 \pm 10.3$ & $<0.001$ \\
BMI $\left(\mathrm{kg} / \mathrm{m}^{2}\right)$ & $24.2 \pm 3.1$ & $24.6 \pm 3.1$ & $<0.001$ \\
FPG $(\mathrm{mg} / \mathrm{dL})$ & $169.2 \pm 34.1$ & $132.9 \pm 27.6$ & $<0.001$ \\
HbA1c $(\%)$ & $8.1 \pm 0.8$ & $7.2 \pm 0.7$ & $<0.001$ \\
IRI $(\mu \mathrm{U} / \mathrm{mL})$ & $7.2 \pm 4.4$ & $6.0 \pm 3.6$ & $<0.001$ \\
HOMA-IR & $3.2 \pm 2.4$ & $2.0 \pm 1.4$ & $<0.001$ \\
Resistin $(\mathrm{ng} / \mathrm{mL})$ & $12.3 \pm 6.4$ & $10.7 \pm 5.8$ & $<0.001$ \\
Adiponectin $(\mu \mathrm{g} / \mathrm{mL})$ & $6.2 \pm 3.2$ & $15.3 \pm 8.4$ & $<0.001$ \\
hsCRP $(\mathrm{mg} / \mathrm{dL})$ & $0.12 \pm 0.15$ & $0.08 \pm 0.11$ & 0.014 \\
\hline Study 2 & Before & After & $P$ \\
\hline BW $(\mathrm{kg})$ & $62.1 \pm 12.3$ & $63.3 \pm 12.4$ & $<0.001$ \\
BMI $\left(\mathrm{kg} / \mathrm{m}^{2}\right)$ & $25.2 \pm 3.3$ & $25.7 \pm 3.5$ & $<0.001$ \\
HbA1c $(\%)$ & $8.9 \pm 1.3$ & $7.5 \pm 1.3$ & $<0.001$ \\
\hline
\end{tabular}

Data are means \pm SD. The value of 12 weeks was compared with that of 0 week by paired $t$ test. Study 1 , prospective study $(n=121)$; Study 2, retrospective study $(n=63)$. FPG, fasting plasma glucose; IRI, immunoreactive insulin; HOMA-IR, homeostasis model assessment insulin resistance index; hsCRP, high-sensitivity C-reactive protein.

ment in blood glucose control whereas no association was found between $\triangle$ HOMA-IR and either $\Delta$ resistin, $\Delta$ adiponectin, or $\triangle \mathrm{hsCRP}(P=0.5761,0.6706$, and 0.6177 , respectively).

We then compared clinical parameters among resistin SNP-420 genotypes. In Study 1, there were no significant differences in age, gender, the duration of diabetes, BMI, FPG, HbA1c, HOMA-IR, adiponectin, insulin, or hsCRP among the SNP -420 genotypes (Table 2). When assessed by multiple regression analysis involving SNP-420 as independent variables, where $\mathrm{C} / \mathrm{C}, \mathrm{C} / \mathrm{G}$, and $\mathrm{G} / \mathrm{G}$ were denoted by two dummy variables $(\mathrm{c} 1, \mathrm{c} 2)=(0,0),(1,0)$, and $(0,1)$, respectively, HOMA-IR was positively correlated with the $\mathrm{G} / \mathrm{G}$ genotype compared to the $\mathrm{C} / \mathrm{C}$ genotype (unstandardized regression coefficient ( $\beta=1.85, P=0.018$ ).

Fasting serum resistin was highest in patients with the $\mathrm{G} / \mathrm{G}$ genotype, followed in order by those with the $\mathrm{C} / \mathrm{G}$ and $\mathrm{C} / \mathrm{C}$ genotypes, both before and 12 weeks after pioglitazone treatment $(P<0.0001$, and $P<0.00001$, respectively) (Table 2 ). When the difference in average value was compared, $\triangle \mathrm{FPG}$ (12 minus 0 weeks), $\Delta$ HOMA-IR (12 minus 0 weeks), and $\Delta$ resistin (12 minus 0 weeks) appeared to be lowest in the G/G genotype, but neither of them reached a statistically significant difference assessed by Kruskal-Wallis test which had a relatively weak power. Since pioglita- 
Table 2. Characteristics of patients with type 2 diabetes by SNP -420 genotype.

\begin{tabular}{|c|c|c|c|c|}
\hline \multirow[t]{2}{*}{ Study 1} & \multicolumn{3}{|c|}{ SNP-420 genotype } & \multirow[b]{2}{*}{$P$} \\
\hline & $\mathrm{C} / \mathrm{C}$ & $\mathrm{C} / \mathrm{G}$ & $\mathrm{G} / \mathrm{G}$ & \\
\hline$n$ (males / females) & $55(31 / 24)$ & $54(29 / 25)$ & $12(7 / 5)$ & $0.939 *$ \\
\hline Age (years) & $63.9 \pm 9.4$ & $65.0 \pm 8.5$ & $61.1 \pm 9.8$ & 0.399 \\
\hline Duration of Diabetes (years) & $11.6 \pm 6.9$ & $12.0 \pm 6.3$ & $10.9 \pm 9.3$ & 0.859 \\
\hline BMI $\left(\mathrm{kg} / \mathrm{m}^{2}\right)$ & $24.4 \pm 3.3$ & $24.0 \pm 3.0$ & $23.5 \pm 2.9$ & 0.664 \\
\hline \multicolumn{5}{|l|}{ FPG (mg/dL) } \\
\hline Before & $166.3 \pm 31.9$ & $170.2 \pm 32.1$ & $185.5 \pm 50.3$ & 0.242 \\
\hline After & $132.9 \pm 24.2$ & $132.9 \pm 30.2$ & $131.4 \pm 30.4$ & 0.985 \\
\hline$\Delta \mathrm{FPG}$ & $-31.1 \pm 33.2$ & $-37.3 \pm 32.8$ & $-54.1 \pm 34.6$ & 0.116 \\
\hline \multicolumn{5}{|l|}{$\mathrm{HbA1c}(\%)$} \\
\hline Before & $8.0 \pm 0.7$ & $8.0 \pm 0.7$ & $8.5 \pm 1.3$ & 0.151 \\
\hline After & $7.1 \pm 0.6$ & $7.3 \pm 0.7$ & $7.6 \pm 1.2$ & 0.088 \\
\hline$\Delta \mathrm{HbAlc}$ & $-0.9 \pm 0.8$ & $-0.8 \pm 0.7$ & $-0.9 \pm 0.7$ & 0.832 \\
\hline \multicolumn{5}{|l|}{ HOMA-IR } \\
\hline Before & $2.9 \pm 1.8$ & $3.2 \pm 2.1$ & $4.7 \pm 4.6$ & $0.493 * *$ \\
\hline After & $1.8 \pm 0.9$ & $2.1 \pm 1.7$ & $2.1 \pm 1.0$ & $0.535 * *$ \\
\hline$\triangle$ HOMA-IR & $-1.0 \pm 1.5$ & $-1.1 \pm 2.1$ & $-2.6 \pm 3.9$ & $0.543 * *$ \\
\hline \multicolumn{5}{|l|}{ Resistin (ng/mL) } \\
\hline Before & $10.0 \pm 5.3$ & $13.0 \pm 5.9$ & $19.5 \pm 7.4$ & $<0.0001^{* *}$ \\
\hline After & $8.0 \pm 3.5$ & $12.1 \pm 6.2$ & $16.4 \pm 6.2$ & $<0.00001 * *$ \\
\hline$\Delta$ Resistin & $-2.1 \pm 3.8$ & $-0.8 \pm 2.9$ & $-3.1 \pm 3.5$ & $0.274 * *$ \\
\hline \multicolumn{5}{|l|}{ Adiponectin $(\mu \mathrm{g} / \mathrm{mL})$} \\
\hline Before & $6.0 \pm 2.9$ & $6.6 \pm 3.7$ & $5.1 \pm 1.5$ & 0.303 \\
\hline After & $14.8 \pm 7.7$ & $16.3 \pm 9.2$ & $13.2 \pm 7.8$ & 0.433 \\
\hline$\Delta$ Adiponectin & $8.8 \pm 5.7$ & $9.7 \pm 6.3$ & $8.1 \pm 7.2$ & 0.611 \\
\hline \multicolumn{5}{|l|}{ IRI $(\mu \mathrm{U} / \mathrm{mL})$} \\
\hline Before & $6.6 \pm 3.6$ & $7.4 \pm 4.2$ & $9.3 \pm 7.6$ & $0.572 * *$ \\
\hline After & $5.7 \pm 3.2$ & $6.2 \pm 4.1$ & $6.2 \pm 2.7$ & $0.663 * *$ \\
\hline$\Delta \mathrm{IRI}$ & $-0.95 \pm 3.5$ & $-1.2 \pm 3.9$ & $-3.1 \pm 5.4$ & $0.610 * *$ \\
\hline \multicolumn{5}{|l|}{ hsCRP (mg/dL) } \\
\hline Before & $0.12 \pm 0.16$ & $0.11 \pm 0.13$ & $0.14 \pm 0.15$ & $0.669 * *$ \\
\hline After & $0.08 \pm 0.11$ & $0.08 \pm 0.11$ & $0.08 \pm 0.15$ & $0.777 * *$ \\
\hline$\Delta \mathrm{hsCRP}$ & $-0.04 \pm 0.18$ & $-0.03 \pm 0.16$ & $-0.06 \pm 0.09$ & $0.468 * *$ \\
\hline \multirow[t]{2}{*}{ Study 2} & \multicolumn{3}{|c|}{ SNP-420 genotype } & \\
\hline & $\mathrm{C} / \mathrm{C}$ & $\mathrm{C} / \mathrm{G}$ & $\mathrm{G} / \mathrm{G}$ & $P$ \\
\hline$n$ (males / females) & $30(11 / 19)$ & $27(12 / 15)$ & $6(2 / 4)$ & $0.790 *$ \\
\hline Age (years) & $66.0 \pm 8.8$ & $63.7 \pm 10.8$ & $65.2 \pm 11.8$ & 0.695 \\
\hline Duration of Diabetes (years) & $18.2 \pm 16.7$ & $16.5 \pm 14.0$ & $12.2 \pm 7.8$ & $0.774 * *$ \\
\hline $\operatorname{BMI}\left(\mathrm{kg} / \mathrm{m}^{2}\right)$ & $25.4 \pm 3.1$ & $25.0 \pm 3.5$ & $24.6 \pm 2.2$ & 0.814 \\
\hline \multicolumn{5}{|l|}{$\mathrm{HbA}_{1 \mathrm{C}}(\%)$} \\
\hline Before & $8.7 \pm 1.3$ & $9.0 \pm 1.1$ & $9.2 \pm 1.6$ & 0.639 \\
\hline After & $7.5 \pm 1.3$ & $7.9 \pm 1.3$ & $6.5 \pm 0.8$ & 0.051 \\
\hline$\Delta \mathrm{HbA}_{1 \mathrm{C}}$ & $-1.3 \pm 1.0$ & $-1.2 \pm 1.3$ & $-2.7 \pm 2.3$ & 0.033 \\
\hline
\end{tabular}

Data are means $\pm \mathrm{SD}$ or $n . P$ value reflects differences between three groups and was assessed by ANOVA unless otherwise indicated. *, $P$ value assessed by Chi-squared test. $* *, P$ value assessed by Kruskal-Wallis test. $\Delta$, the value of each parameter at 12 weeks minus that before pioglitazone treatment. Study 1, prospective study $(n=121)$; Study 2, retrospective study ( $n=63)$. FPG, fasting plasma glucose; IRI, immunoreactive insulin; HOMA-IR, homeostasis model assessment insulin resistance index; hsCRP, high-sensitivity C-reactive protein.

zone is known to be more effective in females and obese subjects [8], possible differences in changes of $\triangle \mathrm{FPG}, \Delta$ HOMA-IR, and $\Delta$ resistin among SNP-420 genotypes, should merit further analyses adjusted for gender and BMI.

To more precisely determine whether $\triangle \mathrm{FPG}$ and $\triangle$ HOMA-IR were correlated with SNP-420 genotypes, these parameters were assessed by multiple regression analysis involving SNP-420 (c1, c2) as independent variables (Table 3). The reduction of FPG and HOMA-IR was correlated with the G/G genotype compared to the $\mathrm{C} / \mathrm{C}$ genotype $(P=0.040$ and 0.029 , 
Table 3. SNP-420 G/G genotype was an independent factor in the reduction of FPG and HOMA-IR by pioglitazone in Study 1.

\begin{tabular}{lcccccccc}
\hline \multicolumn{7}{c}{$\Delta \mathrm{FPG}(\mathrm{mg} / \mathrm{dL})$} & \multicolumn{7}{c}{$\Delta$ HOMA-IR } \\
\hline $\begin{array}{l}\text { Independent } \\
\text { variable; SNP-420 } \\
\text { (G/G) }\end{array}$ & $\begin{array}{c}\text { Unstandardized } \\
\text { regression } \\
\text { coefficient }\end{array}$ & $\begin{array}{c}\text { Standard } \\
\text { error }\end{array}$ & $\begin{array}{c}\text { Standardized } \\
\text { regression } \\
\text { coefficient }\end{array}$ & $P$ & $\begin{array}{c}\text { Unstandardized } \\
\text { regression } \\
\text { coefficient }\end{array}$ & $\begin{array}{c}\text { Standard } \\
\text { error }\end{array}$ & $\begin{array}{c}\text { Standardized } \\
\text { regression } \\
\text { coefficient }\end{array}$ & $P$ \\
\hline Model 1 & & & & & & & & \\
C/G & -6.176 & 6.688 & -0.092 & 0.358 & -0.035 & 0.424 & -0.008 & 0.934 \\
G/G & -22.987 & 11.064 & -0.208 & 0.040 & -1.550 & 0.701 & -0.220 & 0.029 \\
Model 2 & & & & & & & -0.199 & 0.036 \\
Age & -0.784 & 0.341 & -0.213 & 0.023 & -0.047 & 0.022 & -0.029 & 0.763 \\
Gender & -14.735 & 6.330 & -0.220 & 0.022 & -0.124 & 0.409 & -0.247 & 0.009 \\
BMI & -1.855 & 0.976 & -0.173 & 0.060 & -0.169 & 0.063 & -0.004 & 0.969 \\
C/G & -4.803 & 6.376 & -0.072 & 0.453 & -0.016 & 0.412 & -0.004 \\
G/G & -24.739 & 10.561 & -0.224 & 0.021 & -1.772 & 0.683 & -0.252 & 0.011 \\
Pioglitazone (mg) & 0.001 & 0.007 & 0.011 & 0.907 & 0.000 & 0.000 & -0.077 & 0.420 \\
\hline
\end{tabular}

Multiple regression analysis involving either $\triangle \mathrm{FPG}(\mathrm{mg} / \mathrm{dL})$ or $\triangle \mathrm{HOMA}-\mathrm{IR}$ as a dependent variable was performed as described in Subjects and methods. Model 1: SNP-420 genotype, C/C, C/G, and G/G were denoted by two dummy variables $(\mathrm{c} 1, \mathrm{c} 2)=(0,0),(1,0)$, and $(0,1)$, respectively, and were involved as independent variables. Adjusted $\mathrm{R}^{2}$ values were $0.022(\triangle \mathrm{FPG})$, and 0.029 ( $\triangle \mathrm{HOMA}-\mathrm{IR})$. Model 2: In addition to SNP-420 genotype, age (years), age (years), gender (male $=1$, female $=2), \mathrm{BMI}$, and total dose of pioglitazone for 12 weeks $(\mathrm{mg})$ were involved as independent variables. Adjusted $\mathrm{R}^{2}$ values were $0.121(\triangle \mathrm{FPG})$, and $0.092(\triangle \mathrm{HOMA}-\mathrm{IR})$. When treatment of sulfonylurea (with=1, without $=0$ ), metformin (with=1, without=0), $\alpha$-glucosidase inhibitor (with=1, without $=0$ ), and glinide (with=1, without $=0$ ) were involved as independent variables in addition to model $2, P$ values for $\mathrm{G} / \mathrm{G}$ are $0.022(\Delta \mathrm{FPG})$ and $0.013(\Delta \mathrm{HOMA}-\mathrm{IR})$.

respectively) (model 1 in Table 3), which remained significant when adjusted by age, gender, and BMI ( $P=0.020$, and 0.012 , respectively). The further adjustment by total dose of pioglitazone for 12 weeks did not affect these findings (model 2, $P=0.021$ and 0.011 ). The further adjustment by oral hypoglycemic agents had no effects $(P=0.022$, and 0.013$)$. The effect of $\mathrm{G} / \mathrm{G}$ genotype appeared to be relevant since the standardized regression coefficients of $\mathrm{G} / \mathrm{G}$ genotype was comparable to that of BMI. Therefore, the G/ $\mathrm{G}$ genotype was an independent determinant for both $\triangle \mathrm{FPG}$ and $\triangle \mathrm{HOMA}-\mathrm{IR}$.

In Study 2, there were no significant differences in age, gender, the duration of diabetes, and BMI. $\mathrm{HbA1c}$ levels after 12 weeks of treatment appeared to be lowest in the G/G genotype, which did not reach a statistically significant difference among the SNP420 genotypes. The $\Delta \mathrm{HbA} 1 \mathrm{c}$ values $(0-12$ weeks $)$ in Study 2 appeared to be lowest in G/G genotype, which was not found in Study 1, with the caution that the number of the $\mathrm{G} / \mathrm{G}$ group was relatively small.

Since the inconsistency of the correlation between the SNP-420 genotype and $\Delta \mathrm{HbA} 1 \mathrm{c}$ may have resulted from the lack of the power, we combined the Study 1 and Study 2. The heterogeneity of these two studies was adjusted as an independent variable (Study $1=1$, and Study 2=2). The reduction of $\mathrm{HbA} 1 \mathrm{c}$ was greater in the $\mathrm{G} / \mathrm{G}$ genotype when adjusted by age, gender, and BMI ( $\beta=-0.511, P=0.044)$. When further adjusted by the total dose of pioglitazone for 12 weeks, $\beta$ and $P$ values were similar $(\beta=-0.494$ and $P=0.052)$, although this did not reach a statistical significance. The further adjustment by OHA treatment had no effects $(\beta=-$ 0.473 , and $P=0.063$ ). Although marginal, this possible correlation between the $\mathrm{G} / \mathrm{G}$ genotype of resistin SNP -420 and $\Delta \mathrm{HbA} 1 \mathrm{c}$ supports our observation that the $\mathrm{G} / \mathrm{G}$ genotype may be a promising predictor of the reduction of FPG and HOMA-IR by pioglitazone.

\section{Discussion}

The present study suggests that the G/G genotype of resistin SNP -420 may be an independent predictor of the reduction of FPG and HOMA-IR by pioglitazone treatment in type 2 diabetes. In Study 1, multiple regression analysis revealed that the $\mathrm{G} / \mathrm{G}$ genotype was correlated with the reduction of FPG by pioglitazone, independent of age, gender, BMI, OHA treatment, and total dose of pioglitazone. The G/G geno- 
type was also an independent factor for the reduction in HOMA-IR. When studies 1 and 2 were combined, the reduction of $\mathrm{HbAlc}$ was also correlated with this genotype, supporting the above proposal.

In Study 1, we have shown that the G/G genotype was correlated with the reduction in FPG and HOMAIR by pioglitazone. Our group reported that plasma resistin was highest in subjects with $\mathrm{G} / \mathrm{G}$, followed by $\mathrm{C} / \mathrm{G}$ and $\mathrm{C} / \mathrm{C}$ genotype in controls, type 2 diabetic subjects, and the Japanese general population [22, 24, 25]. We also reported that plasma resistin was positively associated with HOMA-IR in large numbers of the general population [25], and that serum resistin levels were associated with insulin resistance in type 2 diabetic patients by using minimal model analysis [29]. Most recently, in "humanized resistin mice", where human resistin is specifically expressed in macrophages and the endogenous resistin is disrupted, high fat diet has induced insulin resistance with the inflammation in adipose tissue [30]. The reduction of serum resistin could result in that of insulin resistance in humans.

Although the reduction of serum resistin is expected to be correlated with that of FPG and HOMA-IR, only that between serum resistin and FPG was found using multiple regression analysis in the present study. The correlation between SNP-420 genotype and the reduction of FRG or HOMA-IR was found only in multiple regression analysis. This was possibly due to the lack of power from the relatively small number of samples, especially divided into each genotype. The relation between SNP-420 and the reduction of serum resistin, FPG, and HOMA-IR by pioglitazone should be pursued using a larger number of samples. The absolute value of resistin after pioglitazone treatment remained higher in the G/G genotype than the others, suggesting that the enhanced resistin gene expression in subjects with the $\mathrm{G} / \mathrm{G}$ genotype may have remained higher.

PPAR- $\gamma$ is expressed in adipose tissues, monocytes, and macrophages $[1,31]$. Resistin was identified as a gene whose expression is inhibited by TZDs in 3T3 L1 adipocytes. In humans, it has been reported that TZDs suppress serum resistin levels in vivo and resistin secretion from monocytes or macrophages in vitro $[32,33]$. It has been reported that TZDs suppress angiotensin II receptor, or thromboxane receptor gene expression, through modulating $\mathrm{Sp} 1$ activity in vascular smooth muscle cells by a direct physical interaction between PPAR- $\gamma$ and Sp1 [34]. One report suggests that PPAR- $\gamma$ activation with TZD represses the expression of the mouse resistin gene by modulating Sp1 activity via O-glycosylation in 3T3-L1 adipocytes [35]. Sp1 binding sites of the mouse resistin gene promoter were required for mediating this repression. In the human resistin gene, we and others showed that Sp1/3 bound the DNA element including G but not C at $-420[24,36]$. Since the human resistin gene promoter with $\mathrm{G}$ at -420 could recruit more $\mathrm{Sp} 1$ factors than that with $\mathrm{C}$, the former may have more prominent reduction of serum resistin by TZDs. Effects of pioglitazone on resistin mRNA in isolated human monocytes having each genotype of SNP-420, and the involvement of $\mathrm{Sp} 1 / 3$ signaling in this process merit further investigation.

Adiponectin is a secreted protein that is abundantly expressed in adipocytes [37]. In a past study, administration of adiponectin was found to improve insulin resistance caused by a reduction in serum adiponectin in obese diabetic mice [38]. In another study, replacement therapy with adiponectin restored insulin sensitivity in adiponectin (-/-) mice [39]. Therefore, the role of adiponectin as an adipocytokine that improves insulin sensitivity has been established in mice. In humans, many studies have demonstrated that TZDs stimulate serum adiponectin levels and improve insulin resistance, resulting in improvement in blood glucose control [40]. In the present study, we found a 2.5 fold increase of serum adiponectin levels after pioglitazone treatment, which is consistent with previous reports. It was reported that pioglitazone ameliorates insulin resistance and diabetes by both adiponectin-dependent and -independent pathways [41]. Improvement of insulin resistance with low-dose pioglitazone was related to the significant up-regulation of serum adiponectin levels in ob/ob mice, whereas large-doses of pioglitazone contributed to the reduction of both resistin and $\mathrm{TNF} \alpha$ in adiponectin-deficient ob/ob mice. It is possible that adiponectin, as well as resistin or TNF $\alpha$, may contribute to the improvement of blood glucose control by pioglitazone treatment.

This study had several limitations. First, the reduction in $\mathrm{HbA} 1 \mathrm{c}$ was significantly greater in the $\mathrm{G} /$ G genotype in Study 2, but not in Study 1. This may be due to differences in the characteristics of patients between the two groups. The female patients were more frequent, and BMI and $\mathrm{HbA} 1 \mathrm{c}$ before pioglitazone treatment were higher in Study 2 than in Study 1. Whether female subjects with higher BMI, and higher $\mathrm{HbA1c}$ could be better responders to pioglitazone, es- 
pecially when having the $\mathrm{G} / \mathrm{G}$ genotype, merits further investigation. Second, in Study 1, whereas multiple regression analysis showed that the reduction of FPG and HOMA-IR was correlated with the G/G genotype, the differences did not reach a statistical significance when assessed by Kruskal-Wallis test. In addition, $P$ values in multiple regression analyses did not remain significant when conservative Bonferroni's correction was applied. Since the sample size of each genotype was relatively small, a larger number of subjects should be analyzed for replication studies.

In conclusion, the present pilot study suggests that the $\mathrm{G} / \mathrm{G}$ genotype of resistin SNP -420 could be a promising predictor of the reduction of FPG and HOMA-IR by pioglitazone treatment in type 2 diabetes. Blinded randomized prospective studies using a larger number sample size are needed to confirm this hypothesis.

\section{Acknowledgements}

This work was supported by Grants from Scientific Research from the Ministry of Education, Culture, Sports, Science, and Technology of Japan and Ehime University. We thank T. Takasuka for technical assistance.

\section{References}

1. Spiegelman BM (1998) PPAR-gamma: adipogenic regulator and thiazolidinedione receptor. Diabetes 47: 507-514.

2. Kahn SE, Haffner SM, Heise MA, Herman WH, Holman RR, Jones NP, Kravitz BG, Lachin JM, O’Neill MC, Zinman B, Viberti G (2006) Glycemic durability of rosiglitazone, metformin, or glyburide monotherapy. N Engl J Med 355: 2427-2443.

3. Miyazaki Y, Mahankali A, Matsuda M, Glass L, Mahankali S, Ferrannini E, Cusi K, Mandarino LJ, DeFronzo RA (2001) Improved glycemic control and enhanced insulin sensitivity in type 2 diabetic subjects treated with pioglitazone. Diabetes Care 24: 710-719.

4. Hanefeld M, Brunetti P, Schernthaner GH, Matthews DR, Charbonnel BH (2004) One-year glycemic control with a sulfonylurea plus pioglitazone versus a sulfonylurea plus metformin in patients with type 2 diabetes. Diabetes Care 27: 141-147.

5. Mazzone T, Meyer PM, Feinstein SB, Davidson MH, Kondos GT, D’Agostino RB, Sr., Perez A, Provost JC, Haffner SM (2006) Effect of pioglitazone compared with glimepiride on carotid intima-media thickness in type 2 diabetes: a randomized trial. JAMA 296: 25722581.

6. Dormandy JA, Charbonnel B, Eckland DJ, Erdmann E, Massi-Benedetti M, Moules IK, Skene AM, Tan MH, Lefebvre PJ, Murray GD, Standl E, Wilcox RG, Wilhelmsen L, Betteridge J, Birkeland K, Golay A, Heine RJ, Koranyi L, Laakso M, Mokan M, Norkus A, Pirags V, Podar T, Scheen A, Scherbaum W, Schernthaner G, Schmitz O, Skrha J, Smith U, Taton J (2005) Secondary prevention of macrovascular events in patients with type 2 diabetes in the PROactive Study (PROspective pioglitAzone Clinical Trial In macroVascular Events): a randomised controlled trial. Lancet 366: 1279-1289.
7. Nissen SE, Wolski K (2007) Effect of rosiglitazone on the risk of myocardial infarction and death from cardiovascular causes. $N$ Engl J Med 356: 2457-2471.

8. Kawamori R, Kadowaki T, Onji M, Seino Y, Akanuma Y (2007) Hepatic safety profile and glycemic control of pioglitazone in more than 20,000 patients with type 2 diabetes mellitus: postmarketing surveillance study in Japan. Diabetes Res Clin Pract 76: 229-235.

9. Satoh N, Ogawa Y, Usui T, Tagami T, Kono S, Uesugi H, Sugiyama H, Sugawara A, Yamada K, Shimatsu A, Kuzuya H, Nakao K (2003) Antiatherogenic effect of pioglitazone in type 2 diabetic patients irrespective of the responsiveness to its antidiabetic effect. Diabetes Care 26: 2493-2499.

10. Hansen L, Ekstrom CT, Tabanera YPR, Anant M, Wassermann K, Reinhardt RR (2006) The Pro12Ala variant of the PPARG gene is a risk factor for peroxisome proliferator-activated receptor-gamma/alpha agonist-induced edema in type 2 diabetic patients. J Clin Endocrinol Metab 91: 3446-3450.

11. Kang ES, Cha BS, Kim HJ, Kim HJ, Kim SH, Hur KY, Lee HJ, Shim WS, Ahn CW, Lee HC (2006) The $11482 \mathrm{G}>\mathrm{A}$ polymorphism in the perilipin gene is associated with weight gain with rosiglitazone treatment in type 2 diabetes. Diabetes Care 29: 1320-1324.

12. Steppan CM, Bailey ST, Bhat S, Brown EJ, Banerjee RR, Wright CM, Patel HR, Ahima RS, Lazar MA (2001) The hormone resistin links obesity to diabetes. Nature 409: 307-312.

13. Banerjee R, Rangwala S, Shapiro J, Rich A, Rhoades B, Qi Y, Wang J, Rajala M, Pocai A, Scherer P, Steppan C, Ahima R, Obici S, Rossetti L, Lazar M (2004) Regulation of fasted blood glucose by resistin. Science 303: 1195-1198.

14. Rangwala S, Rich A, Rhoades B, Shapiro J, Obici S, Rossetti L, Lazar M (2004) Abnormal glucose homeo- 
stasis due to chronic hyperresistinemia. Diabetes 53: 1937-1941.

15. Patel L, Buckels A, Kinghorn I, Murdock P, Holbrook J, Plumpton C, Macphee C, Smith S (2003) Resistin is expressed in human macrophages and directly regulated by PPAR gamma activators. Biochem Biophys Res Commun 300: 472-476.

16. Savage D, Sewter C, Klenk E, Segal D, Vidal-Puig A, Considine R, O’Rahilly S (2001) Resistin / Fizz3 expression in relation to obesity and peroxisome proliferator-activated receptor-gamma action in humans. Diabetes 50: 2199-2202.

17. Weisberg S, McCann D, Desai M, Rosenbaum M, Leibel R, Ferrante AJ (2003) Obesity is associated with macrophage accumulation in adipose tissue. $J$ Clin Invest 112: 1796-1808.

18. Cho Y, Youn B, Chung S, Kim K, Lee H, Yu K, Park H, Shin H, Park K (2004) Common genetic polymorphisms in the promoter of resistin gene are major determinants of plasma resistin concentrations in humans. Diabetologia 47: 559-565.

19. Engert JC, Vohl MC, Williams SM, Lepage P, Loredo-Osti JC, Faith J, Dore C, Renaud Y, Burtt NP, Villeneuve A, Hirschhorn JN, Altshuler D, Groop LC, Despres JP, Gaudet D, Hudson TJ (2002) 5' flanking variants of resistin are associated with obesity. Diabetes 51: 1629-1634.

20. McTernan P, Fisher F, Valsamakis G, Chetty R, Harte A, McTernan C, Clark P, Smith S, Barnett A, Kumar S (2003) Resistin and type 2 diabetes: regulation of resistin expression by insulin and rosiglitazone and the effects of recombinant resistin on lipid and glucose metabolism in human differentiated adipocytes. J Clin Endocrinol Metab 88: 6098-6106.

21. Osawa H, Onuma H, Murakami A, Ochi M, Nishimiya T, Kato K, Shimizu I, Fujii Y, Ohashi J, Makino H (2002) Systematic search for single nucleotide polymorphisms in the resistin gene: The absence of evidence for the association of three identified single nucleotide polymorphisms with Japanese type 2 diabetes. Diabetes 51: 863-866.

22. Osawa H, Onuma H, Ochi M, Murakami A, Yamauchi J, Takasuka T, Tanabe F, Shimizu I, Kato K, Nishida W, Yamada K, Tabara Y, Yasukawa M, Fujii Y, Ohashi J, Miki T, Makino H (2005) Resistin SNP-420 determines its monocyte mRNA and serum levels inducing type 2 diabetes. Biochem Biophys Res Commun 335: 596-602.

23. Smith S, Bai F, Charbonneau C, Janderova L, Argyropoulos G (2003) A promoter genotype and oxidative stress potentially link resistin to human insulin resistance. Diabetes 52: 1611-1618.

24. Osawa H, Yamada K, Onuma H, Murakami A, Ochi M, Kawata H, Nishimiya T, Niiya T, Shimizu I, Nishida W, Hashiramoto M, Kanatsuka A, Fujii Y, Ohashi J, Makino H (2004) The G/G genotype of a resistin sin- gle-nucleotide polymorphism at -420 increases type 2 diabetes mellitus susceptibility by inducing promoter activity through specific binding of Sp1/3. Am J Hum Genet 75: 678-686.

25. Osawa H, Tabara Y, Kawamoto R, Ohashi J, Ochi M, Onuma H, Nishida W, Yamada K, Nakura J, Kohara K, Miki T, Makino H (2007) Plasma resistin, associated with single nucleotide polymorphism -420 , is correlated with insulin resistance, lower HDL, and high sensitivity CRP in the Japanese general population. Diabetes Care 30: 1501-1506.

26. Arita Y, Kihara S, Ouchi N, Takahashi M, Maeda K, Miyagawa J, Hotta K, Shimomura I, Nakamura T, Miyaoka K, Kuriyama H, Nishida M, Yamashita S, Okubo K, Matsubara K, Muraguchi M, Ohmoto Y, Funahashi T, Matsuzawa Y (1999) Paradoxical decrease of an adipose-specific protein, adiponectin, in obesity. Biochem Biophys Res Commun 257: 79-83.

27. Aso Y, Yamamoto R, Wakabayashi S, Uchida T, Takayanagi K, Takebayashi K, Okuno T, Inoue T, Node K, Tobe T, Inukai T, Nakano Y (2006) Comparison of serum high-molecular weight (HMW) adiponectin with total adiponectin concentrations in type 2 diabetic patients with coronary artery disease using a novel enzyme-linked immunosorbent assay to detect HMW adiponectin. Diabetes 55: 1954-1960.

28. Ridker PM (2001) High-sensitivity C-reactive protein: potential adjunct for global risk assessment in the primary prevention of cardiovascular disease. Circulation 103: 1813-1818.

29. Tokuyama Y, Osawa H, Ishizuka T, Onuma H, Matsui K, Egashira T, Makino H, Kanatsuka A (2007) Serum resistin level is associated with insulin sensitivity in Japanese type 2 diabetes. Metabolism 56: 693-698.

30. Qatanani M, Szwergold N, Greaves D, Ahima R, Lazar M (2009) Macrophage-derived human resistin exacerbates adipose tissue inflammation and insulin resistance in mice. J Clin Invest in press.

31. Ricote M, Li AC, Willson TM, Kelly CJ, Glass CK (1998) The peroxisome proliferator-activated receptorgamma is a negative regulator of macrophage activation. Nature 391: 79-82.

32. Bajaj M, Suraamornkul S, Hardies LJ, Pratipanawatr T, DeFronzo RA (2004) Plasma resistin concentration, hepatic fat content, and hepatic and peripheral insulin resistance in pioglitazone-treated type II diabetic patients. Int J Obes Relat Metab Disord 28: 783-789.

33. Lehrke M, Reilly MP, Millington SC, Iqbal N, Rader DJ, Lazar MA (2004) An inflammatory cascade leading to hyperresistinemia in humans. PLoS Med 1: e45.

34. Sugawara A, Takeuchi K, Uruno A, Ikeda Y, Arima S, Kudo M, Sato K, Taniyama Y, Ito S (2001) Transcriptional suppression of type 1 angiotensin II receptor gene expression by peroxisome proliferator-activated receptor-gamma in vascular smooth muscle cells. 
Endocrinology 142: 3125-3134.

35. Chung SS, Choi HH, Kim KW, Cho YM, Lee HK, Park KS (2005) Regulation of human resistin gene expression in cell systems: an important role of stimulatory protein 1 interaction with a common promoter polymorphic site. Diabetologia 48: 1150-1158.

36. Chung SS, Choi HH, Cho YM, Lee HK, Park KS (2006) Sp1 mediates repression of the resistin gene by PPARgamma agonists in 3T3-L1 adipocytes. Biochem Biophys Res Commun 348: 253-258.

37. Kadowaki T, Yamauchi T (2005) Adiponectin and adiponectin receptors. Endocr Rev 26: 439-451.

38. Yamauchi T, Kamon J, Waki H, Terauchi Y, Kubota N, Hara K, Mori Y, Ide T, Murakami K, TsuboyamaKasaoka N, Ezaki O, Akanuma Y, Gavrilova O, Vinson C, Reitman ML, Kagechika H, Shudo K, Yoda M, Nakano Y, Tobe K, Nagai R, Kimura S, Tomita M, Froguel P, Kadowaki T (2001) The fat-derived hormone adiponectin reverses insulin resistance associated with both lipoatrophy and obesity. Nat Med 7: 941-946.

39. Maeda N, Shimomura I, Kishida K, Nishizawa H, Matsuda M, Nagaretani H, Furuyama N, Kondo H, Takahashi M, Arita Y, Komuro R, Ouchi N, Kihara S, Tochino Y, Okutomi K, Horie M, Takeda S, Aoyama T, Funahashi T, Matsuzawa Y (2002) Diet-induced insulin resistance in mice lacking adiponectin/ACRP30. Nat Med 8: 731-737.

40. Bouskila M, Pajvani UB, Scherer PE (2005) Adiponectin: a relevant player in PPARgamma-agonistmediated improvements in hepatic insulin sensitivity? Int J Obes (Lond) 29 Suppl 1: S17-23.

41. Kubota N, Terauchi Y, Kubota T, Kumagai H, Itoh S, Satoh H, Yano W, Ogata H, Tokuyama K, Takamoto I, Mineyama T, Ishikawa M, Moroi M, Sugi K, Yamauchi T, Ueki K, Tobe K, Noda T, Nagai R, Kadowaki T (2006) Pioglitazone ameliorates insulin resistance and diabetes by both adiponectin-dependent and -independent pathways. J Biol Chem 281: 8748-8755. 